\title{
HAK PATEN SERTA CONTOH STUDY KASUS PADA PRODUK SONY ERICSSON \\ ARIEF DARMAWAN 155100007
}

Fakultas Komputer, 4487572-44

Ariefdermawan.student@umitra.ac.id

\begin{abstract}
Pertama kali mari kita dalami mengenai definisi paten yang seringkali kita dengar ini. pada dasarnya, paten merupakan hak yang khusus diberikan oleh Negara kepada seorang penemu atas hasil penemuannya di bidang teknologi, untuk jangka waktu tertentu melaksanakan sendiri atas penemuannya tersebut atau memberikan persetujuannya kepada oranglain untuk melaksanakannya (Pasal 1 Ayat 1 UU mengenai Paten).

Kali ini, artikel yang saya tulis ini akan membahas mengenai paten dari sebuah merk SONY ERICSSON. Pada awal perkembangan SONY ERICSSON bermula atau muncul degan nama tersebut hingga kini telah berganti nama menjadi Sony Mobile Communications Inc. Sony Mobile Communications Inc adalah perusahaan pembuat telepon genggam yang didirikan pada tahun 2001 hasil gabungan dari dua perusahaan besar dalam dua bidang yang berbeda: perusahaan Jepang, Sony (elektronik) dan perusahaan Swedia Ericsson (telekomunikasi seluler). Tahun 2012 saham Ericsson di perusahaan ini telah dibeli sepenuhnya oleh Sony. Pada kuarter pertama tahun 2012, Sony Mobile merupakan perusahaan pembuat ponsel terbesar kesepuluh di dunia.

Berbicara mengenai Sony Mobile Communications Inc, sebelum berganti nama menjadi nama besar seperti ini, tidak terlepas dari 2 orang tokoh yang besar dikenal sebagai pendiri dari perusahaan ini telah menjadi cikal bakal dari berdirinya perusahaan tersebut. Kedua tokoh tersebut yaitu Akio Morita (pendiri Sony) dan Larn Magnus Ericcson (Pendiri Ericsson) yang pada awalnya mempunyai perusahaan yang berdiri sendiri hingga pada akhirnya memutuskan untuk berkolaborasi untuk membentuk suatu ciptaan baru yang patut diperhitungkan dan mampu bersaing di dunia bisnis di negara tersebut bahkan diluar negara tersebut.
\end{abstract}

Kata Kunci : Paten, teknologi, elektronik, kuarter, dan kolaborasi. 


\section{A. INTRODUCTION}

Sebagai pendahuluan dari artikel yang saya tulis ini, pertama kali mari kita dalami mengenai definisi paten yang seringkali kita dengar ini. pada dasarnya, paten merupakan hak yang khusus diberikan oleh Negara kepada seorang penemu atas hasil penemuannya di bidang teknologi, untuk jangka waktu tertentu melaksanakan sendiri atas penemuannya tersebut atau memberikan persetujuannya kepada oranglain untuk melaksanakannya (Pasal 1 Ayat 1 UU mengenai PATEN).

Dalam paten, terdapat seseorang yang disebut dengan inventor. Inventor merupakan seseorang atau lebih yang bersama-sama melaksanakan ide yang dituangkan ke dalam kegiatan yang menghasilkan invensi (atau sebuah temuan).

Berikut adalah aturan-aturan mengenai PATEN :

- UNDANG - UNDANG (UU) MENGENAI PATEN DI INDONESIA.

- UU Nomor 13 Tahun 2016 mengenai Paten.

- UU Nomor 14 Tahun 2001 mengenai Paten.

- Penjelasan UU Nomor 14 Tahun 2001 tentang Paten.
- PERATURAN

PEMERINTAH BIDANG PATEN :

(PP)

- Peraturan Pemerintah

Republik Indonesia Nomor 27 Tahun 2004 tentang

Tata Cara Pelaksanaan Paten oleh Pemerintah ditetapkan Tanggal 5 Oktober tahun 2004.

- Peraturan Pemerintah Republik Indonesia Nomor 31 Tahun 1995 mengenai Komisi Banding Paten ditetapkan Tanggal 29 Agustus 1995.

- Peraturan Pemerintah Republik Indonesia Nomor 11 Tahun 1993 mengenai Bentuk dan Isi Surat Paten ditetapkan Tanggal 22 Februari 1993.

- Peraturan Pemerintah Republik Indonesia Nomor 33 Tahun 1991 tentang Pendaftaran Khusus Konsultan Paten ditetapkan Tanggal 11 Juni 1991.

- Peraturan Pemerintah Republik Indonesia Nomor 45 Tahun 2016 tentang Jenis Dan Tarif Atas Penerimaan Negara Bukan Pajak Yang Berlaku Pada 
Kementerian Hukum dan

Hak Asasi Manusia.

- PERATURAN PRESIDEN REPUBLIK INDONESIA BIDANG PATEN :

- Peraturan Presiden

Republik Indonesia No. 76

Tahun 2012 Tentang

Pelaksanaan Paten Oleh

Pemerintah Terhadap Obat

Antiviral dan

Antiretroviral.

- PERATURAN MENTERI HUKUM DAN HAM RI NO. 15 TAHUN 2018 TENTANG PELAKSANAAN PATEN OLEH PEMEGANG

PATEN :

- Peraturan Menteri Hukum dan HAM RI No. 15 Tahun 2018 Tentang Pelaksanaan Paten oleh Pemegang Paten

- KEPUTUSAN PRESIDEN (KEPPRES) REPUBLIK INDONESIA :

- Keputusan Presiden Republik Indonesia Nomor 83 Tahun 2004 tentang Pelaksanaan Paten oleh Pemerintah terhadap Obatobat Anti Retroviral.

Kali ini, artikel yang saya tulis ini akan membahas mengenai paten dari sebuah merk SONY ERICSSON. Pada awal perkembangan SONY ERICSSON bermula atau muncul degan nama tersebut hingga kini telah berganti nama menjadi Sony Mobile Communications Inc. Sony Mobile Communications Inc adalah perusahaan pembuat telepon genggam yang didirikan pada tahun 2001 hasil gabungan dari dua perusahaan besar dalam dua bidang yang berbeda: perusahaan Jepang, Sony (elekt ronik) dan perusahaan Swedia Ericsson (telekomunikasi

seluler). Tahun 2012 saham Ericsson di perusahaan ini telah dibeli sepenuhnya oleh Sony. Pada kuarter pertama tahun 2012, Sony Mobile merupakan perusahaan pembuat ponsel terbesar kesepuluh di dunia.

Menyangkut mengenai kepemilikan atau kepatenan dari produk tersebut. Tidak terlepas dari 2 tokoh besar sebagai pemilik paten dari produk tersebut yaitu Akio Morita (pendiri Sony) dan Larn Magnus Ericcson (Pendiri Ericsson).

1. Sejarah singkat mengenai awal berdirinya perusahaan sony oleh Akio Morita. 


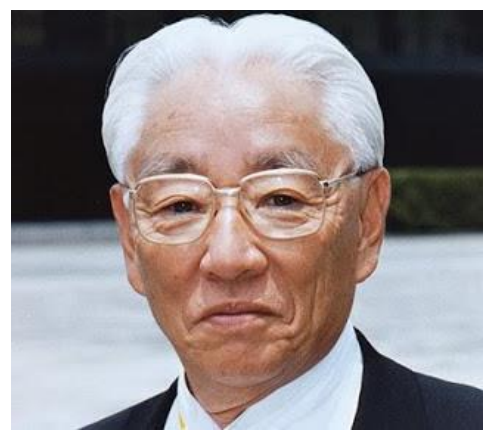

Sony didirikan pada $7 \mathrm{Mei}$ 1946 dengan nama Perusahaan Telekomunikasi Tokyo dengan sekitar 20 karyawan. Produk konsumen mereka yang pertama adalah sebuah penanak nasi pada akhir 1940-an. Seiring dengan berkembangnya Sony sebagai perusahaan internasional yang besar, ia membeli perusahaan lain yang mempunyai sejarah yang lebih lama termasuk Columbia Records (perusahaan rekaman tertua yang masih ada, didirikan pada tahun 1888). Nama "Sony" dipilih sebagai gabungan kata Latin sonus, yang merupakan akar dari sonik dan bunyi, dan kata Inggris sonny ("anak kecil") yang setelah dikombinasikan berarti sekelompok kecil anak muda yang memiliki energi dan kemauan keras terhadap kreasi dan inovasi ide yang tak terbataskan. Pada saat itu, sangatlah aneh bagi sebuah perusahaan Jepang untuk menggunakan huruf Roman untuk mengeja namanya, apalagi penggunaan aksara fonetis yang digunakan dalam penulisan bahasa Jepang (daripada menggunakan aksara Tionghoa). Dan pada 1958, perusahaan mulai secara formal mengadopsi nama "Sony Corporation" sebagai nama perusahaan. Mudah digunakan dan mudah dieja dalam segala bahasa dunia. Nama Sony menggaungkan semangat kebebasan dan keterbukaan dalam inovasi.

2. Sejarah singkat mengenai awal berdirinya perusahaan Ericsson oleh Larn Magnus Ericcson (Pendiri Ericsson).

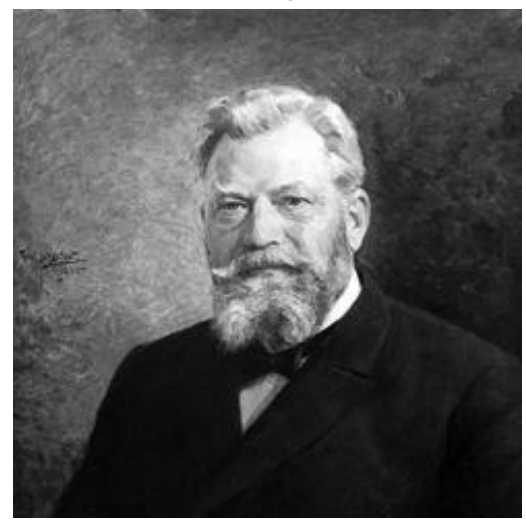

Didirikan pada 1876 sebagai toko peralatan perbaikan telegram oleh Lars Magnus Ericsson, ia dimasukkan pada Agustus 18, 1918. Berkantor pusat di Kista, Kota Stockholm, sejak tahun 2003, AY Ericsson dianggap bagian dari apa yang disebut "Wireless Valley". Sejak 
pertengahan 1990-an, Ericsson yang sangat luas di Stockholm membantu mentransformasi modal menjadi salah satu sentra-sentra penelitian teknologi informasi (TI) Eropa. Ericsson memiliki kantor dan beroperasi di lebih dari 150 negara, dengan lebih dari 20.000 staf di Swedia, dan juga di presences signifikan, misalnya, Cina, Inggris, Amerika Serikat, Finlandia, Irlandia, dan Brasil.

Pada awal abad 20, Ericsson mendominasi pasar dunia untuk pertukaran telepon manual (manual telephone exchanges) tetapi terlambat untuk memperkenalkan peralatan telepon otomatis. Terbesar di dunia sepanjang sejarah sebagai pertukaran telepon manual, melayani 60.000 baris, dipasang oleh Ericsson di Moskow pada 1916. Sepanjang tahun 1990an, Ericsson yang diadakan 35$40 \%$ pangsa pasar telepon selular terpasang sistem. Seperti kebanyakan dari industri telekomunikasi, AY Ericsson menderita kerugian berat setelah telekomunikasi crash pada awal 2000, dan harus merumahkan puluhan ribu staf di seluruh dunia sebagai upaya untuk mengelola situasi keuangan, berhasil meraih keuntungan kembali pertengahan tahun 2000 .

Pada tahun 2001 divisi handset yang dibentuk dari joint venture dengan Sony disebut Sony Ericsson. AY
Ericsson sekarang besar penyedia handset core dan infrastruktur pemasok utama bagi semua teknologi nirkabel. Ia telah memainkan peran penting dalam global Modernisasi tembaga yang ada baris untuk menawarkan layanan broadband dan telah tumbuh secara aktif baru bidang usaha di wilayah layanan profesional.

\section{B. CONCLUSION}

Kesimpulannya, pada dasarnya, paten merupakan hak yang khusus diberikan oleh Negara kepada seorang penemu atas hasil penemuannya di bidang teknologi, untuk jangka waktu tertentu. Paten merupakan suatu hak yang dimiliki oleh seseorang yang memiliki kemampuan untuk menemukan sesuatu yang spektakuler yang diakui. Dalam paten, terdapat seseorang yang disebut dengan inventor. Inventor merupakan seseorang atau lebih yang bersama-sama melaksanakan ide yang dituangkan ke dalam kegiatan yang menghasilkan invensi (atau sebuah temuan).

Berbicara mengenai Sony Mobile Communications Inc, sebelum berganti nama menjadi nama besar seperti ini, tidak terlepas dari 2 orang tokoh yang besar dikenal sebagai pendiri dari perusahaan ini telah menjadi cikal bakal dari berdirinya perusahaan tersebut. Kedua tokoh tersebut 
yaitu Akio Morita (pendiri Sony) dan Larn Magnus Ericcson (Pendiri Ericsson) yang pada awalnya mempunyai perusahaan yang berdiri sendiri hingga pada akhirnya memutuskan untuk berkolaborasi untuk membentuk suatu ciptaan baru yang patut diperhitungkan dan mampu bersaing di dunia bisnis di negara tersebut bahkan diluar negara tersebut.

C. ACKNOWLEDGEMENT University Of Indonesia University Of Mitra Indonesia Telkom University University Of Mellbourne Saitama University

\section{REFERENCE(Based ISO 690 )}

A. S. Putra And O. M. Febriani, "Knowledge Management Online Application In Pdam Lampung Province," In Prosiding International Conference On Information Technology And Business (Icitb), 2018, Pp. 181-187.

[2] A. S. Putra, O. M. Febriani, And B. Bachry, "Implementasi Genetic Fuzzy System Untuk Mengidentifikasi Hasil Curian Kendaraan Bermotor Di Polda Lampung," J. Sist. Inf. Dan Manaj. Basis Data, Vol. 1, No. 1, Pp. 21-30, 2018.

[3] O. M. Febriani And A. S. Putra, "Sistem Informasi Monitoring Inventori Barang Pada Balai
Riset Standardisasi Industri Bandar Lampung," J. Inform., Vol. 13, No. 1, Pp. 90-98, 2014.

[4] Putra, Arie Setya. "2018 Artikel Struktur Data, Audit Dan Jaringan Komputer." (2018).

[5] Putra, A. S. (2018, July 17). Paperplain Fundamental Create Application With Borland Delphi 7.0 University Of Mitra Indonesia. Retrieved From Osf.Io/Pbrn9.

\section{E. REFERENCE(Based APA )}

Putra, A. S., Aryanti, D. R., \& Hartati, I. (2018, November). Metode SAW (Simple Additive Weighting) sebagai Sistem Pendukung Keputusan Guru Berprestasi (Studi Kasus: SMK Global Surya). In Prosiding Seminar Nasional Darmajaya (Vol. 1, No. 1, pp. 85-97).

Sari, D. P., Febriani, O. M., \& Putra, A. S. (2018, November). Perancangan Sistem Informasi SDM Berprestasi pada SD Global Surya. In Prosiding Seminar Nasional Darmajaya (Vol. 1, No. 1, pp. 289-294).

Putra, A. S. (2018). Paperplain: Execution Fundamental Create Application With Borland Delphi 7.0 University Of Mitra Indonesia.

Putra, A. S., Sukri, H., \& Zuhri, K. Sistem Monitoring Realtime Jaringan Irigasi Desa (JIDES) Dengan Konsep Jaringan Sensor Nirkabel. IJEIS (Indonesian Journal of Electronics and Instrumentation Systems), 8(2), 221232. 
Darmawan, A., Yuliawati, D., Marcella, O., \& Firmandala, R. (2016). Sistem Absensi dan Pelaporan Berbasis Fingerprint dan SMS Gateway. EXPLORE, 7(1).

Febriani, O. M., Wahyuni, T., \& Yusuf, S. (2017). DESIGN OF WEBSITE-BASED INFORMATION SYSTEM FOR EDOCUMENT ADMINISTRASI IN THE COMMUNITY SERVICE UNIT (A Case Study at Rajabasa District). INTERNATIONAL JOURNAL OF COMPUTERS \& TECHNOLOGY, 16(7), 7010-7020.

Febriani, O. M., \& Wahyuni, T. (2017, October). PERANCANGAN SISTEM E-DOCUMENT ADMINISTRASI LOGBOOK PENELITIAN PADA UNIT LAYANAN DI BANDAR LAMPUNG. In Prosiding Seminar Nasional Darmajaya (Vol. 1, No. 1, pp. 187-194).

Febriani, O. M., \& Permadi, A. B. (2017). Implementasi Sistem Aplikasi Data Bimbingan dan Pelanggaran Siswa pada Sekolah Menengah Atas di Lampung Tengah dengan Metode Analisis dan Desain Sistem Terdistribusi (SSAD). EXPERT, 7(1).

Febriani, O. M., \& Ambarwati, L. (2015). PERANCANGAN APLIKASI PENGOLAHAN DATA PENJUALAN UKM KELANTING KHAS TELO DESA SIDOHARJO KECAMATAN JATI AGUNG KABUPATEN LAMPUNG SELATAN. Jurnal Teknologi Informasi dan Bisnis Pengabdian Masyarakat Darmajaya, 1(1), 77-95.
Febriani, O. M. (2015). Rancang Bangun Aplikasi Ecommercemenggunakan Freewebstore pada UKM Kelanting di Desa Sidoharjo Lampung Selatan. Prosiding Sembistek 2014, 1(02), 446-458. 